\title{
Strong differences characterize Microcystis blooms between successive severe drought years in the San Francisco Estuary, California, USA
}

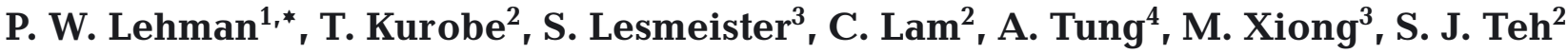 \\ ${ }^{1}$ California Department of Fish and Wildlife, Stockton, California 95206, USA \\ ${ }^{2}$ Department of Anatomy, Physiology and Cell Biology, School of Veterinary Medicine, University of California, Davis, \\ California 95616, USA \\ ${ }^{3}$ California Department of Water Resources, West Sacramento, California 95691, USA \\ ${ }^{4}$ Department of Wildlife, Fish, and Conservation Biology, University of California, Davis, California 95616, USA
}

\begin{abstract}
The frequency, intensity and duration of cyanobacterial harmful algal blooms are expected to increase with climate change. Here we tested the null hypothesis that successive severe drought years would not differ in the magnitude, community composition and controlling factors for Microcystis blooms during 2014 and 2015, the third and fourth most severe drought years on record in the San Francisco Estuary, California, USA. Identical sets of physical, chemical and biological data were collected every 2 wk at 10 stations between August and November for each year. Primary producer biomass, abundance, biovolume, community composition and toxin production were quantified. Contrary to expectation, the surface and subsurface Microcystis bloom in 2014 was at least an order of magnitude greater than in 2015, the drier and warmer year. In addition, the 2015 drought had a greater percentage of other cyanobacteria (non-Microcystis) and eukaryotic phytoplankton than 2014. Median water quality conditions were similar between years, but correlations among physical, chemical and biological variables often differed in magnitude and direction. PRIMER DISTLM (BEST) analysis identified water temperature, the landward extent of saltwater intrusion and outflow as variables that accounted for the most variation in Microcystis surface biovolume $\left(\mathrm{R}^{2}=0.48\right)$ or subsurface abundance $\left(\mathrm{R}^{2}=0.45\right)$. We conclude that the magnitude of Microcystis blooms may not always increase with drought severity or prolonged drought, and are dependent on within-year spatial and temporal variation.
\end{abstract}

KEY WORDS: Microcystis $\cdot$ Drought $\cdot$ Cyanobacteria $\cdot$ Bloom $\cdot$ Estuary $\cdot$ Water quality $\cdot$ CHAB

\section{INTRODUCTION}

The frequency, intensity and duration of harmful algal blooms of Microcystis spp. (MICI) are expected to increase with the predicted increase in drought conditions due to climate change (Harke et al. 2016). MICI is one of the most common freshwater cyanobacteria,

${ }^{*}$ Corresponding author: peggy.lehman@wildlife.ca.gov and has increased with drought periods worldwide, including the Murray and Edward Rivers, Australia (Bowling et al. 2016), the Nakong River, South Korea (Ha et al. 1999), and the Guadiana River, Spain and Portugal (Moreno et al. 2004). However, little is known about how MICI varies with physical, chemical and biological factors between successive drought years. 
Toxic MICI blooms have occurred in the San Francisco Estuary (SFE) since 1999 (Lehman et al. 2017). MICI abundance and total microcystin concentration were greater during dry than wet years in SFE, and increased by at least an order of magnitude over previous years during the 2014 severe drought (Lehman et al. 2017). Elevated water temperature and reduced streamflow were associated with MICI biovolume and toxin concentration (Lehman et al. 2008a, 2017). Understanding the cause(s) of MICI blooms is important in SFE, where research suggests that total microcystin concentration can affect the health and survival of phytoplankton, zooplankton and fish (Ger et al. 2010, Lehman et al. 2010, Acuña et al. 2012, Kurobe et al. 2018).

The purpose of this research was to test the null hypothesis that the magnitude, primary producer community composition and controlling factors associated with the MICI bloom would not differ between successive severe drought years in SFE. These hypotheses were tested by comparing spatial and temporal variation in physical, chemical and biological variables during the bloom seasons in 2014 and 2015, the third and fourth driest years on record in SFE (http://cdec.water.ca.gov/cgi-progs/iodir/WSIHIST).

\section{MATERIALS AND METHODS}

\section{Study site}

SFE contains an inland delta (Delta) of $2990 \mathrm{~km}^{2}$ with $1100 \mathrm{~km}$ of waterways, which receives water from the Sacramento and San Joaquin Rivers (Fig. 1). Water depth varies from a few meters in flooded islands to $13 \mathrm{~m}$ in river channels. Tides reach $2 \mathrm{~m}$ in height, velocities up to $30 \mathrm{~cm} \mathrm{~s}^{-1}$ and excursions of $10 \mathrm{~km}$. Nutrients occur in excess, but do not lead to eutrophic conditions due to light limitation from suspended sediment (Jassby 2008).

\section{Field sampling and analyses}

Sampling was conducted every 2 wk between August and early November at 10 stations $(n=140)$ within the Sacramento and San Joaquin Rivers in 2014 and 2015 (Fig. 1). Physical conditions were measured by a YSI sonde. Surface MICI colonies were collected by hand towing a plankton net $(75 \mu \mathrm{m}$ mesh). Water samples for measurement of cyanotoxins (by ELISA), nutrients, pigment concentration, total and dissolved organic carbon and total and volatile suspended solid concentrations, as well as wholewater primary producer composition and abundance (by qPCR and microscopy) were collected by a van Dorn bottle at $0.3 \mathrm{~m}$ depth. Details of the laboratory analytical methods are described by Lehman et al. (2017). Streamflow data were obtained from the DAYFLOW database (www.water.ca.gov).

\section{Statistical analyses}

Multiple and single comparisons, ordination and multiple regression analysis were conducted using PRIMER v.7 software (Clarke \& Gorley 2015) and SAS (SAS Institute 2013). Due to collinearity ( $r>0.95$ ), specific conductance (EC) was used to represent total dissolved solids and chloride. Deviations from the median were computed as median absolute deviation (MAD).

\section{RESULTS}

\section{Environmental conditions}

Median streamflow was similar $(\mathrm{p}>0.05)$ at Rio Vista (RIO) on the Sacramento River in 2014 (93 \pm $\left.17 \mathrm{~m}^{3} \mathrm{~s}^{-1}\right)$ and $2015\left(87 \pm 21 \mathrm{~m}^{3} \mathrm{~s}^{-1}\right)$, but decreased from $10 \pm 2 \mathrm{~m}^{3} \mathrm{~s}^{-1}$ in 2014 to $7 \pm 4 \mathrm{~m}^{3} \mathrm{~s}^{-1}$ in 2015 on the San Joaquin River (SJR, p $<0.01$, Fig. S1a,b in the Supplement at www.int-res.com/articles/suppl/a081 p293_supp.pdf). The distance landward from the Pacific Ocean where the bottom salinity is 2 (X2) was also further upstream in $2014(89 \pm 2 \mathrm{~km})$ than in 2015

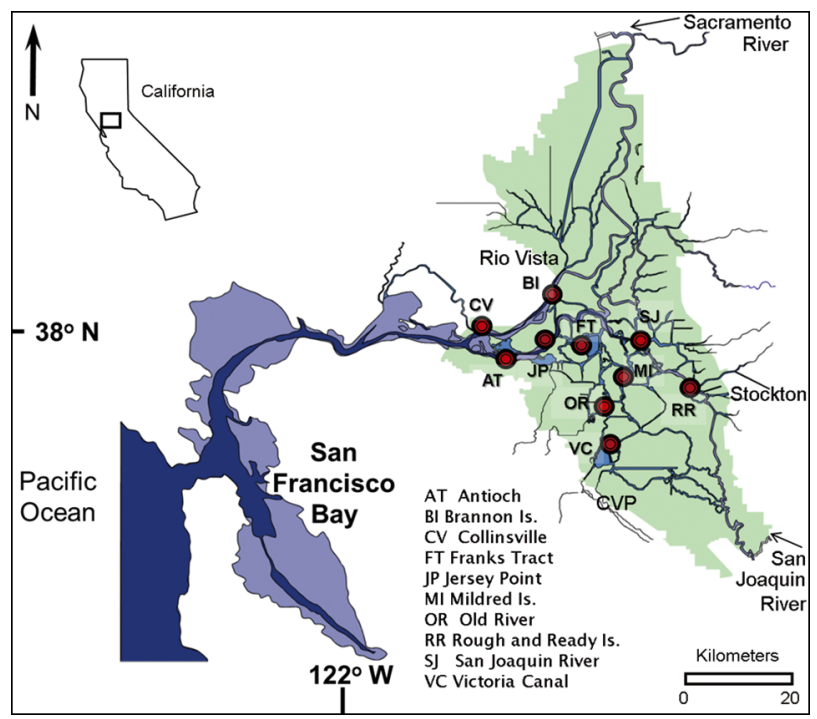

Fig. 1. Map of San Francisco Estuary showing the location of sampling stations 
( $86 \pm 1$ km, $p<0.01$, Fig. S1c), particularly during the peak of the bloom in August and September. Similarly, total river outflow (OUT) was less for 2014 (99 \pm $\left.17 \mathrm{~m}^{3} \mathrm{~s}^{-1}\right)$ than for $2015\left(136 \pm 21 \mathrm{~m}^{3} \mathrm{~s}^{-1}\right)(\mathrm{p}<0.01)$ during the peak of the bloom (Fig. S1d).

Only soluble reactive phosphorus (SRP), silica $\left(\mathrm{SiO}_{2}\right)$, integrated euphotic zone light (LITE) and $\mathrm{pH}$ were greater in 2014 than 2015 over the bloom season (August through November; Table 1). August and September (summer) had higher $\mathrm{SRP}, \mathrm{SiO}_{2}$, dissolved oxygen and $\mathrm{pH}$ in 2014 than 2015. October and November (fall) had greater LITE and $\mathrm{SiO}_{2}$ in 2014 than 2015, but greater total phosphorus (TP) in 2015 than 2014. Within years, summer had greater water temperature (WT), LITE, percent dissolved oxygen concentration and $\mathrm{pH}$ than the fall, while the fall had greater nitrate $\left(\mathrm{NO}_{3}\right)$, ammonium $\left(\mathrm{NH}_{4}\right), \mathrm{SRP}$ and $\mathrm{SiO}_{2}$ concentration than the summer (Table 1).

\section{Primary producers and toxins}

Surface chlorophyll a concentration (CHLA-S) and surface Microcystis biovolume (MICI-S), as well as subsurface Microcystis abundance (MICI-D) of potentially toxic and non-toxic cells determined by qPCR, and sub-surface total microcystin concentration (TMICN-D) were greater $(p<0.01)$ in 2014 than 2015 over the summer and bloom season (Table 1). CHLA-S and MICI-D were greater for both years in the central and south Delta along the SJR and Old River at Stns FT, JP, MI, OR, RR, SJ and VC (see Fig. 1) than near the confluence of the Sacramento River and SJR at Stns AT, BI and CV ( $p<0.05$; Fig. 2a,e). MICI-S and TMICN-D did not differ between stations due to high variability (Fig. 2c,g). Among months, peak CHLA-S, MICI-S and MICI-D occurred in summer for both years $(p<0.05$; Fig. 2b,d,f). TMICN-D was greater for summer in 2014 ( $p<0.05$; Fig. 2h), but did not differ among months in 2015.

Median percent total subsurface cyanobacteria biovolume (MICI plus other cyanobacteria) in the $>10 \mu \mathrm{m}$ diameter size fraction (microscopy) was greater in 2014 (72 $\pm 27 \%)$ than $2015(55 \pm 26 \%$; p < 0.01; Fig. S2a,b). MICI comprised over half of the total cyanobacteria biovolume in $2014(60 \pm 23 \%)$, but only a quarter of the biovolume $(24 \pm 26 \%$; p < 0.01 ) in 2015. For eukaryotic phytoplankton, cryptophyte biovolume was greater in 2014, while diatom, green algae and chrysophyte biovolume was greater in 2015 ( $p<0.01$; Fig. S2a,b). Diatoms comprised the largest percentage of all eukaryotes, and increased from $12 \pm 14 \%$ to $27 \pm 19 \%$ of the total primary producer biovolume between 2014 and 2015. The percent dinoflagellate biovolume was low, and did not differ between years.

The relative abundance of cyanobacteria in all size fractions within subsurface samples (qPCR) also differed between 2014 and 2015. The percent MICI-D was greater in $2014(14 \pm 7 \%)$ than $2015(4 \pm 5 \%)$ by a factor of 3 , while the percent of potentially toxic MICI-D cells was greater in 2014 ( $3 \pm 3 \%$ ) than 2015 $(0.05 \pm 0.07 \%)$ by over an order of magnitude $(\mathrm{p}<$ 0.01; Fig. S3a,b). The percent Aphanizomenon was also greater in $2014(6 \pm 4 \%)$ than $2015(2 \pm 3 \%$; p < 0.01). In contrast, both Dolichospermum $(0 \%$ and $0.01 \pm 0.01 \% ; \mathrm{p}<0.05)$ and other cyanobacteria $(75 \pm$ $11 \%$ and $92 \pm 9 \% ; \mathrm{p}<0.01$ ) were greater in 2015 than 2014 , respectively.

\section{Correlations}

Correlations among physical and chemical variables differed for 2014 and 2015. RIO and SJR were negatively correlated in 2015, but were not correlated in 2014 (Table S1a,b). WT was correlated with RIO in 2015, but not in 2014. In contrast, WT was correlated with X2 in 2014, but not 2015. Although WT and EC were negatively correlated for both years, the correlation was stronger in 2014 than 2015. Turbidity was more strongly correlated with EC and LITE in 2015 than 2014, while LITE was more strongly correlated with streamflow variables and EC in 2015 than 2014. TP and SJR were positively correlated in 2015 and negatively correlated in 2014. Ammonium concentration was negatively correlated with RIO in 2015, but not 2014 .

The direction and magnitude of correlations between MICI-S and MICI-D, CHLA-S and environmental variables also differed between years. MICID, MICI-S and CHLA-S increased with WT and X2 in 2014, but not 2015 (Table S2). For 2015, MICI-D was less strongly correlated with WT and WEST, and more strongly correlated with nitrogen than in 2014. MICI-D and CHLA-S were also correlated with LITE or RIO and TP in 2015, but not 2014.

An ordination of all environmental variables demonstrated similar water quality conditions, but a large difference in bloom magnitude between the 2 years (Fig. 3). For log transformed values, Akaike's information criterion (AIC) and $\mathrm{R}^{2}$ criteria indicated that a combination of WT and X2 explained the largest amount of variation (adj. $\mathrm{R}^{2}=0.44$ ) in MICI-D for both years combined (PRIMER v.7 DISTLM [BEST] 


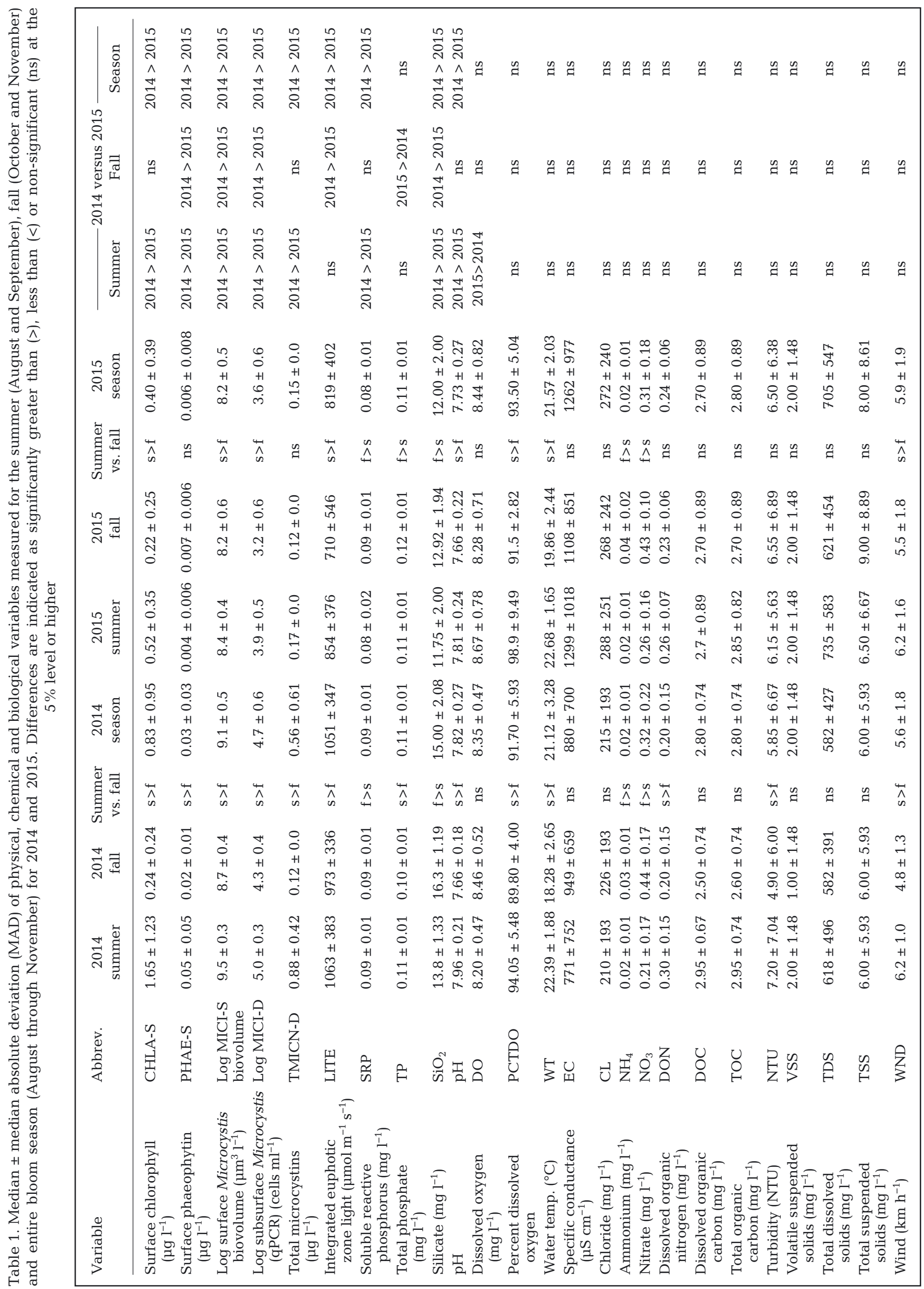



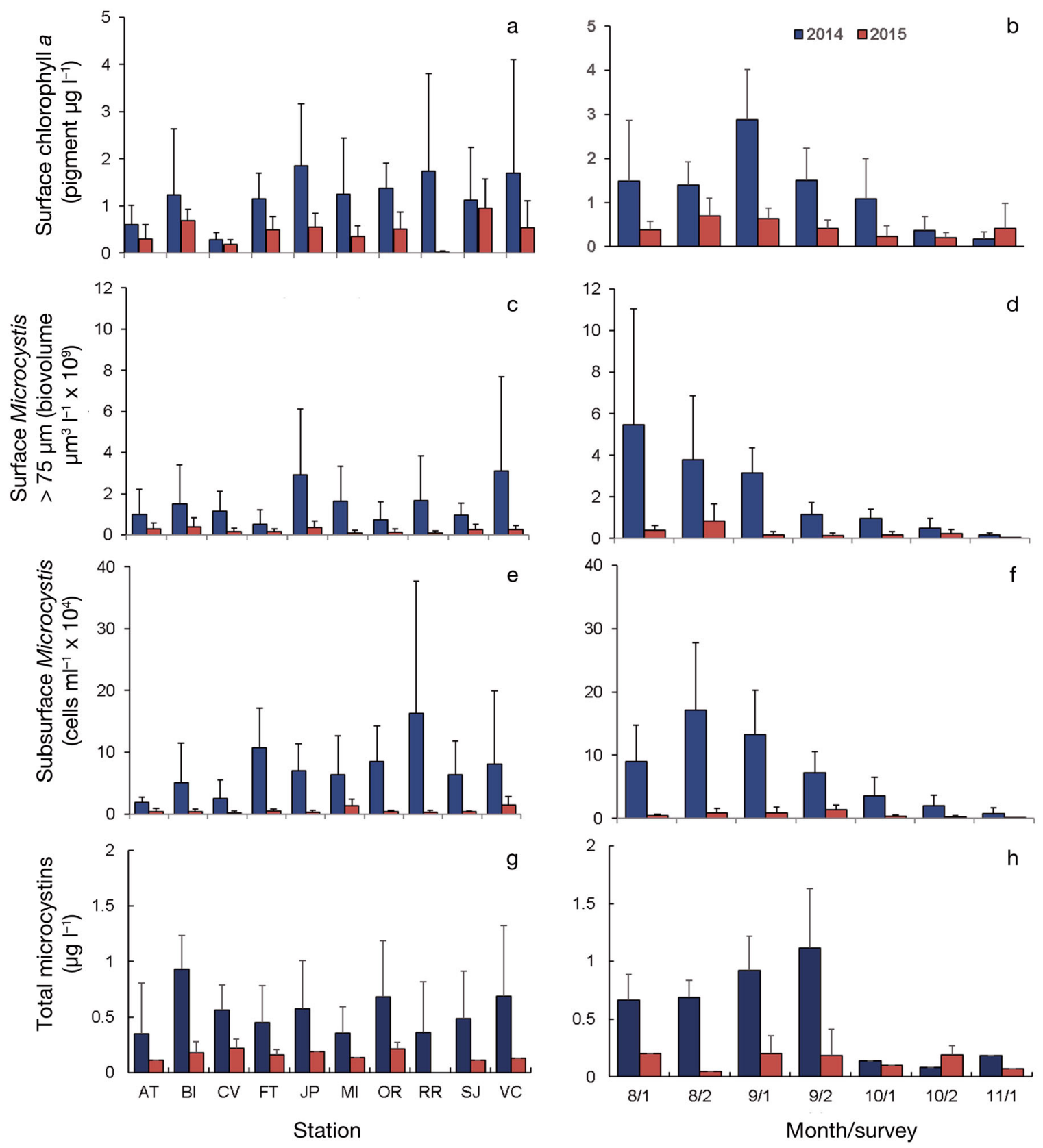

Fig. 2. Median and median absolute deviation (MAD, error bars) by station and month/survey (1 or 2) of $(a, b)$ surface chlorophyll a concentration, (c,d) surface Microcystis biovolume (>75 $\mu \mathrm{m}$ size fraction, $(\mathrm{e}, \mathrm{f})$ subsurface Microcystis abundance and $(g, h)$ total microcystins measured every 2 wk between August and November in 2014 and 2015 at 10 stations in the Sacramento San Joaquin Delta, California, USA (see Fig. 1 for abbreviations and locations)

analysis; Table 2). Similarly, WT and outflow explained the largest amount of variation (adj. $\mathrm{R}^{2}=$ 0.47 ) in MICI-S for both years combined. A distancebased redundancy analysis (db-RDA ordination) containing only WT and X2 demonstrated a strong separation in MICI-D between years (Fig. S4). Even though median WT values were similar between years (Table 1), the percentage of values above $25^{\circ} \mathrm{C}$ (18\%) was twice as high in 2014 than 2015 (8\%) in summer. Maximum MICI-D occurred when WT was above $24^{\circ} \mathrm{C}$ and $\mathrm{X} 2$ was at $89 \mathrm{~km}$ in 2014 .

\section{DISCUSSION}

We rejected the hypothesis that the MICI bloom would be greater in the climatically drier and warmer severe drought year 2015 compared with 2014. This 


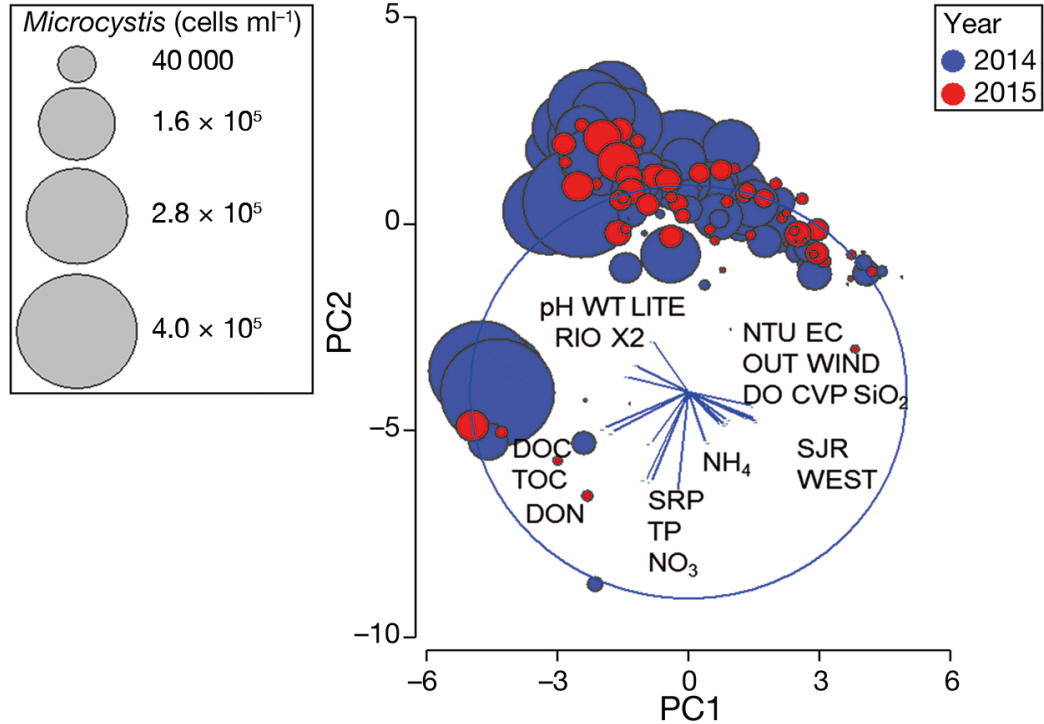

Fig. 3. Ordination of environmental variables overlaid with the abundance of subsurface Microcystis abundance measured every 2 wk between August and early November at 10 stations in 2014 and 2015. See abbreviations of variables in Table 1 plus total outflow (OUT) and the landward extent of salt water intrusion to bottom salinity of 2 (X2)

Table 2. Environmental variables that describe the variation in Microcystis subsurface abundance and surface biovolume determined using PRIMER v7. DISTLM (BEST) analysis for 2014 and 2015. All data were log transformed; in all cases, $\mathrm{p}=0.001 . \mathrm{X} 2$ : distance landward from the Pacific Ocean where the bottom salinity is 2

\begin{tabular}{|lcc|}
\hline Dependent variable & Predictor variable & Adj. R \\
\hline Subsurface Microcystis & X2 & 0.32 \\
abundance & Water temp. & 0.44 \\
Surface Microcystis & Outflow & 0.38 \\
biovolume & Water temp. & 0.47 \\
\hline
\end{tabular}

finding seemed to contradict previous research indicating that the MICI bloom increased with warmer and drier conditions in SFE (Lehman et al. 2017). However, the higher frequency of warm WT during August and September probably favored the growth of more MICI in 2014 than 2015. MICI reaches the peak biomass-specific growth rate in August and September, so an increase in WT during these months would have a large impact on the population (Lehman et al. 2008a). MICI grows well at high WT, and the high relative importance of WT as a controlling factor for MICI growth among a suite of environmental conditions was confirmed in laboratory bioassays (Jiang et al. 2008, Lürling et al. 2017) and field research (Bowling et al. 2016).

Similarly, more frequent WT below $25^{\circ} \mathrm{C}$ during the bloom season in 2015 may partially explain the greater percentage of other cyanobacteria, Dolichospermum and diatoms in 2015 than 2014. Aphanizomenon, Dolichospermum and diatoms are common below $25^{\circ} \mathrm{C}$ worldwide (Carey et al. 2012), and were more common during the unseasonably low WT in the summer of 2011 in SFE (Kurobe et al. 2013).

Due to their impact on colony retention, outflow and X2 were also key factors influencing the magnitude of the MICI blooms in 2014 and 2015. Lower outflow in 2014 than 2015 reduced the movement of colonies seaward near the surface, where the flow is high. Higher X2 in 2014 than 2015 also facilitated accumulation of subsurface colonies by increasing water retention time in the SJR (Jassby et al. 1995). Because MICI has a slow growth rate compared with most primary producers, its abundance is often due more to accumulation than growth (Reynolds 2006). For SFE, maximum biomass-specific growth rate of MICI was less than half of that for nonMICI primary producers (Lehman et al. 2008a,b). MICI blooms commonly develop as a result of low streamflow in rivers or tidal estuaries, including the Murray River, Australia (Bowling et al. 2016), and the Nakong River, South Korea (Ha et al. 1999).

Differences in physical, chemical and biological correlations and the primary producer community suggest there was a shift in the structure and function of the estuary between the 2014 and 2015 droughts. A shift in the primary producer community could have been influenced by MICI, because cyanobacteria can release peptides and alkaloids that are allelopathic to phytoplankton (Paerl \& Paul 2012). In SFE, low abundance of diatoms and green algae coincided with high MICI abundance between 2004 and 2008 (Lehman et al. 2010). The increased diversity of the cyanobacterial community in 2015 may also reflect a change in the overall bacterial community within the SJR (Otten et al. 2017).

Large differences in the bloom magnitude, and correlations among physical, chemical and biological variables for these 2 successive severe drought years, suggest that understanding the cause of cyanobacterial blooms during prolonged severe drought requires knowledge of the variation in environmental and biological variables at multiple spatial and temporal scales. 
Acknowledgements. This research was supported by the California Departments of Fish and Wildlife and Water Resources, the Interagency Ecological Program and State Operations General Fund Special Legislation AB91/92.

\section{LITERATURE CITED}

Acuña S, Deng DF, Lehman P, Teh SJ (2012) Dietary effects of Microcystis on Sacramento splittail, Pogonichthys macrolepidotus. Aquat Toxicol 110-111:1-8

Bowling L, Egan S, Holliday J, Honeyman G (2016) Did spatial and temporal variations in water quality influence cyanobacterial abundance, community composition and cell size in the Murray River, Australia during a droughtaffected low-flow summer? Hydrobiologia 765:359-377

Carey CC, Ibelings BW, Hoffmann EP, Hamilton DP, Brookes JD (2012) Eco-physiological adaptations that favour freshwater cyanobacteria in a changing climate. Water Res 46:1394-1407

Clarke KR, Gorley RN (2015) Getting started with PRIMER v7. PRIMER-E, Plymouth Marine Laboratory, Plymouth

* Ger KA, Teh SJ, Baxa DV, Lesmeister SH, Goldman CR (2010) The effects of dietary Microcystis aeruginosa and microcystin on the copepods of the upper San Francisco Estuary. Freshw Biol 55:1548-1559

* Ha K, Cho E, Kim H, Joo G (1999) Microcystis bloom formation in the lower Nakdong River, South Korea: importance of hydrodynamics and nutrient loading. Mar Freshw Res 50:89-94

Harke MJ, Steffen MM, Gobler CJ, Otten TG, Wilhelm SW, Wood SA, Paerl HW (2016) A review of the global ecology, genomics, and biogeography of the toxic cyanobacterium, Microcystis spp. Harmful Algae 54:4-20

Jassby A D (2008) Phytoplankton in the Upper San Francisco Estuary: recent biomass trends, their causes and their trophic significance. San Francisco Estuary and Watershed Science 6, Article 2. https://escholarship.org/uc/ item/71h077r1

Jassby AD, Kimmerer WJ, Monismith SG, Armor C, Cloern JE, Powell TM, Schubel JR, Venflinski TJ (1995) Isohaline position as a habitat indicator for estuarine populations. Ecol Appl 5:272-289

Jiang Y, Ji B, Wong RNS, Wong MH (2008) Statistical study on the effects of environmental factors on the growth and

Editorial responsibility: Rutger de Wit, Montpellier, France microcystins production of bloom-forming cyanobacterium - Microcystis aeruginosa. Harmful Algae 7:127-136

K Kurobe T, Baxa DV, Mioni CE, Kudela RM and others (2013) Identification of harmful cyanobacteria in the Sacramento-San Joaquin Delta and Clear Lake, California by DNA barcoding. Springerplus 2:491

* Kurobe T, Lehman PW, Haque ME, Sedda T, Lesmeister S, Teh S (2018) Evaluation of water quality during successive severe drought years within Microcystis blooms using fish embryo toxicity tests for the San Francisco Estuary. Sci Total Environ 610-611:1029-1037

* Lehman PW, Boyer G, Satchwell M, Waller S (2008a) The influence of environmental conditions on the seasonal variation of Microcystis cell density and microcystins concentration in San Francisco Estuary. Hydrobiologia 600:187-204

* Lehman PW, Sommer T, Rivard L (2008b) Phytoplankton primary productivity, respiration, chlorophyll a and species composition in the Yolo Bypass floodplain, California. Aquat Ecol 42:363-378

* Lehman PW, Teh SJ, Boyer GL, Nobriga M, Bass E, Hogle C (2010) Initial impacts of Microcystis on the aquatic food web in the San Francisco Estuary. Hydrobiologia 637: 229-248

는 SJ (2017) Impacts of the 2014 severe drought on the Microcystis bloom in San Francisco Estuary. Harmful Algae 63:94-108

米Lürling M, van Oosterhout F, Faassen E (2017) Eutrophication and warming boost cyanobacterial biomass and microcystins. Toxins 9:64

*Moreno IM, Pereira P, Franca S, Cameán A (2004) Toxic cyanobacteria strains isolated from blooms in the Guadiana River (southwestern Spain). Biol Res 37:405-417

Otten TG, Paerl HW, Dreher TW, Kimmerer WJ, Parker AE (2017) The molecular ecology of Microcystis sp. blooms in the San Francisco Estuary Delta. Environ Microbiol 19: 3619-3637

* Paerl HW, Paul VJ (2012) Climate change: links to global expansion of harmful cyanobacteria. Water Res 46: 1349-1363

Reynolds CS (2006) The ecology of phytoplankton. Cambridge University Press, Cambridge

SAS Institute (2013) SAS/STAT user's guide, Version 8. SAS Institute, Cary, NC

Submitted: March 12, 2018; Accepted: May 16, 2018 Proofs received from author(s): July 25, 2018 